\title{
TEACHING BUSINESS ENGLISH WITH THE SUPPORT OF WEBLOGS
}

\author{
Eva Stradiotová, University of Economics in Bratislava, Faculty of \\ Applied Languages, eva.stradiotova@euba.sk
}

Radoslav Štefančik, University of Economics in Bratislava, Faculty of Applied Languages, radoslav.stefancik@euba.sk

DOI: 10.31902/fIl.35.2021.16

\begin{abstract}
In this paper, we focused on the mediation of the research results of using weblogs as a form of supplement to traditional teaching in the classroom and their influence on the development of business writing skills. The aim of the research was to prove that the weblog had an impact on improving the business writing skills and on the motivation of students to devote themselves to write contributions in a foreign language at an increased rate. In the research, we used quantitative research methods such as experiment, pre-test, post-test, and research instrument questionnaire. The research was carried at the University of Economics in Bratislava and 60 respondents took part in the experiment. Through the pre-test and post-test, we found out to what extent were the business writing skills of the respondents of the experimental group influenced by the use of weblogs in teaching business English. We used the student test to analyse the data obtained. The results confirmed that the use of the weblog in teaching business English had an impact on the development of business writing skills. We used the questionnaire to collect data in survey research aimed at finding out to what extent the use of the weblog affected the motivation of respondents to write to a greater extent in a foreign language. The analysis of the responses confirmed that the respondents perceived the weblog as a new, non-traditional form of the supplement to traditional teaching, which had an impact on their motivation to devote themselves more to write in a foreign language. Research has confirmed that the weblog, as one of the tools of Web 2.0, has a positive impact on the development of business writing skills.
\end{abstract}

Keywords: business English, marketing tools, information and communication technology (ICT); economics weblog, internet, Web 2.0.

\section{Introduction}

In the current globalized era, English has become a major means of communication in many areas of life (House, 2003). English is the number one language in science and research, in international politics, in 
international security, but even in commercial art (in the film and music industries) or in sports. Naturally, English is the main means of communication in the sphere of economics, business, but also among academics of Universities of Economics. „English has become the lingua franca of international business” (Anglemark, John, 2018: 406). Many international companies investing in non-English countries require a high level of business English language skills from their employees in managerial positions. English has become a language of communication not only in international management but also in corporate communication (Kankaanranta, Louhiala-Salminen, and Karhunen, 2015). It is therefore natural that graduates of Universities of Economics are required to have a good command of the business English language. Understandably, universities providing education in economic fields emphasize education not only in general English but special attention is paid to teaching business English (Šipragić-Đokić, 2011; Hrdličková, 2017).

However, the process of economic and political globalization is also linked to the technical and technological revolution. Modern technologies affect our daily lives, and, understandably, they have also affected the educational processes. The use of the Internet tools is now a natural part of the life of the younger generation, naturally, young people are those who will require from the university teachers to use these tools in the educational processes not only to make teaching and learning more effective but also more enjoyable. Educators, therefore, try to follow innovative trends in teaching and to incorporate the most up-to-date technology into the educational processes. Many of the most advanced technologies are connected to the virtual world of the Internet, and one of the Web 2.0 tools, namely the weblog, we pay attention to in this paper. In Slovakia, the use of modern means of the Internet was underused, but paradoxically, the Corona-crisis of 2020 has pushed forward the frontiers of the modern ways of teaching.

The article aims to explain what possibilities modern technologies provide for teachers of business English. Technical and technological innovations in the educational processes are now an essential part of a modern approach to teaching, regardless of whether it is related to teaching a foreign language or other subjects. In the paper, we present the results of an experiment in which we tested the use of weblogs as one of the modern didactic methods and its impact on improving business English writing skills.

We work on the assumption that nowadays we can find on the Internet the most different teaching aids in English and Web 2.0 application weblog is one of them. There are several highly specialized and very successful business blogs. Many of the successful business 
blogs contain unique features that attract thousands of readers. Business or economics blogs, therefore, have two educational functions. On the one hand, they expand the vocabulary in the field of economics and business. The functioning of national economies or the world economy is an incredibly dynamic process that constantly generates new and new economic terms. In view of the fact that the global economy is under the influence of developed, industrialized countries, primarily the United States, it is understandable that these terms originate first in English and are later translated into national languages. The second educational function of economics blogs is equally important for a student of economic subjects. Weblogs serve as an important source of business news and financial information (Habermann, 2005; lšoraité, 2015).

Business weblogs can also be perceived as knowledge management tools for entrepreneurs to enhance marketing efforts (Singh, Singh, 2008). A well-prepared blog is a tool of communication with real and potential customers (Cramer, 2013). Business blogs are not only used by large corporations but they can also be used by freelancers like writers, artists, or designers (du Preez, 2012). Students through economics blogs acquire not only language but also important economic knowledge. Economics blogs bring innovative knowledge from the functioning of various economic spheres, marketing, various types of management, but also economic policy or accounting. Thus, the student of economic disciplines is pushing their knowledge forward in business English lessons, although the primary objective of these courses is usually to improve foreign language competence. For this reason, we consider it important to incorporate a weblog into Business English Teaching as a necessary tool for modern and effective education.

\section{Blogs theoretical aspects}

The Internet is the prime mover of communication. Its invention enables us to use the World Wide Web in education (Ma, 2012; Karabacak, Genç, 2019). As the Internet is an essential part of young people's lives (Lacina, Griffith, 2012), it is understandable that the use of Internet tools in education is now more than necessary. Web 2.0 technologies, including wikis, social networks like Facebook or Twitter, and weblogs, have become popular tools for young people (Arquero, Romero-Frías 2013; Ifinedo, 2018). Today, we can no longer imagine a young person not using Internet tools either on his/her computer or on his/her smartphone. Young people even know how to use Internet tools better than the generations before them. It is therefore understandable that young people will expect to use the Internet not only in their free 
time but also in the educational process. Of course, the medium of the Internet has always been available as a means of content production as well as consumption for its users (Brake, 2014: 591), as Tim Berners-Lee (1999: 182) mentioned we ought to be able not only to find any kind of document on the Web but also to create any kind of document, easily and it has been made possible by the development of more sophisticated, database-driven websites that have made it easier for people to create their sites which allow their creators to contribute and spread information to others.

Like other Internet tools, weblogs, or frequently shortened to blogs, are used extensively in the educational process (Arquero, Romero-Frías 2013; Ifinedo, 2018). It has overcome many difficulties to become part of everyday life and these days it is common to have access to the Internet at home, at work, or school even in the shopping malls or get free wi-fi access in public hotspots.

Crystal (2006) defines the Internet as an association of computer networks with common standards that enable messages to be sent from any registered computer (or host) on one network to any host on any other. The fast development of the Internet has also given birth to new web applications. According to Karpova the Internet and modern information technologies with their impact on personality development foster the implementation of differentiated or multilevel teaching of the English language taking into account students' abilities, needs, and aspirations (Karpova, 2017: 11).

One of the most important changes is the evolution of Web 1.0 into Web 2.0, which is focused on the ability for people to collaborate and share information online. Web 2.0 refers to the transition from static HTML web pages to a more dynamic Web that is more organized and is based on serving web applications to users (Laborda, Litzler, 2017). Other improved functionality of Web 2.0 includes open communication with an emphasis on web-based communities of users, and more open sharing of information (Solomon, Schrum, 2010, p. 1). Web 2.0 is the second phase of the World Wide Web that enables us to use more interactive, collaborative, and facilitative features. There are many Web 2.0 technologies and services such as blogs, wikis, syndication of content through RSS, social networks, instant messaging, mash-up and tags, etc., which are the powerful tools that provide a user with interface, flexible web design and social network base (Murugesan, 2007), i.e. Web 2.0 serves as a social web.

Web 2.0 has proved to be a liberal and liberating tool of communication that has empowered citizens, consumers, and employees (Jones, Iredale, 2009: 67). Through the web, people can 
engage in political debate, and through social networks, politicians communicate with their constituents. While in the era of traditional media there was only one-way communication in terms of politicians towards voters, Web 2.0 provides citizens with the opportunity to communicate directly with their political representatives. Of course, it is debatable whether Web 2.0 has deepened liberal democracy, as the Web provides space for a more intensive discussion with voters also for right-wing extremists (Kluknavská, Hruška, 2019).

Web applications such as a weblog, audio blog, video blog, wikis, and other applications are becoming more and more attractive for educators. The tools of Web 2.0 are used increasingly more often in educational settings to overcome the constraints of time and space of the traditional classroom. This proliferation has been leading to major changes in the dissemination of information, sharing of knowledge, and interactions among learners (Bener, Yıldız, 2019: 40).

Today, Web 2.0 is not only used for general education but it can also be used for specific education, including economic education. According to Jones and Iredale (2009), Web 2.0 is a suitable tool for entrepreneurship education.

As we mentioned the weblog is part of Web 2.0. Weblogs are some of the first examples of Web 2.0 technologies and social media. In contrast to Web 1.0, which was about defining and creating destinations for web users, Web 2.0 is about people and content" (Agerdal-Hjermind, 2014). The term Weblog was created by Jorn Barger in 1997. It is a combination of two words "web" and "log". Due to their association with the word 'log' blogs are likened to diaries or journals. The diary-like and journalistic connotations of blogs have been noted by certain researchers (Farmer, Yue, and Brooks, 2008). It takes the form of a personalized web page where the owner can post messages at intervals (Crystal, 2006, 15). Ráthonyi and Várallyai (2011) define Weblog, a blog, or blogging as a type of web site/platform consisting of textual information written in the form of a diary, often containing photos or connections and they are viewed in reverse chronological order (Elega, 2018). As Murray and Hourigan (2008) mentioned the Weblog is asynchronous computer-mediated communication (CMC), which offers another means of online communication. It means that students cannot expect that they will get feedback immediately. As Crystal wrote the weblog is a simple web page that is customized for the public, i.e. the creation of weblog is not difficult and can be managed even by people who do not have technical skills. We can say that the attractiveness of blogs lies in its didactic efficiency such as accessibility (it requires only basic access to the Internet); in ease of use (a minimum of technical 
know-how), the effectiveness of the information space, interactivity, and multimedia. A teacher or a student chooses interlocutors himself/herself and administers the process of communication personally (Kovalchuk, Krasnokutska, 2017).

If we take a closer look at the history of the blog, we would find that the weblog was created at the end of the 20th century, which means that it is a relatively new form of the website that is gradually getting into public awareness. Many people have heard of weblogs, but if you ask them what a weblog is, many of them do not know the answer to this question. According to some sources, there were about 70 million blogs in mid-2005. To date, there are more than 500 million blogs around the world and bloggers publish more than 2 million posts every day, on average.

According to Lin (2013: 577) blogs were created to be used as an online digital writing and publishing tool for interacting with people and writing personal journals, but the use of blogs in educational contexts has attracted great research attention. A weblog enables us to publish text, pictures, and videos. Weblogs allow interactive feedback and comments from other Internet users (Hartman, 2007). Weblogs are currently used for educational purposes in various academic areas, such as the humanities, political science, communication management, or teacher education (Lee, Bonk, 2015). According to Lennon and Barnes (2020: 5), blogging is arguably the most established form of social media used by academics. Kitchakarn (2014) claims that weblogs are currently a widely used tool for teaching foreign languages. According to Jo-Ann Oravec (2002: 616) weblogs provide a format for critiques of other Web materials along with various personal touches. This Internet tool for publication and communication uses the interaction among people to promote cooperative learning skills, the development and sociability of knowledge, and resources for teachers and students, stimulating reading skills, text productions, and virtual communities' formation (Pereira et al., 2019).

\section{Business English and blogs}

With the development of Internet communication tools, the importance of the English language has increased. English is the primary language of communication in the world of information technology. English has a similar position in the economic world (Zoranić, 2010). With economic globalization and the boom of international business and trade, business communication and the use of English as the main language for business have increased significantly (Li, Chen, 2017: 700). „English is a valuable skill for success in the business environment in 
non-English-speaking countries" (Anglemark, John, 2018: 407). However, teaching business English is specific in comparison to teaching general English language. It requires that the English teacher not only demonstrates competence in the foreign language but also good knowledge of economics and management. However, business English teachers do not automatically confirm this assumption. Some authors (Dudley-Evans, St John, 1998; Šipragić-Đokić, 2011) point out that foreign-language competence with the knowledge of how economic processes work is not the same among teachers, yet the link between business principles and language (Dudley- Evans, St John, 1998) should be one of the basic preconditions for teachers of this subject. Studying business English is an excellent opportunity for students of economics to improve their foreign language competence and to gain new economic knowledge. The English-speaking world is a global market leader, English is the main communication language of international economic institutions, and the English language is also an instrument of internal communication in international corporations.

Since the origin of several current economic terms comes from English, blogs in English are an important didactic tool in teaching business English. As early as the beginning of the 21st century, blogs had been an important means of communication for large companies, but they were gradually displaced by other, simpler forms of Internet communication, especially social networks. Despite this trend, existing corporate blogs have still been a widely used tool in foreign language teaching, not only to expand vocabulary but also to deepen economic knowledge.

Blogs can be used in a variety of ways (Quible, 2005). The public knows blogs mostly as the result of an individual's communication with the public in the form of personal comments on various topics (Išoraité, 2015). On the web portals of Slovak dailies, we will primarily encounter political blogs, but cooking blogs are no exception. However, blogs also provide enough space for business communication. In addition to social networks, blogs can become a means of corporate communication with their real or potential customers. Blogs are thus part of corporate marketing. The advantage of blogs over social networks is that they can provide more information to potential customers. They are not limited by space.

According to Filimon et al. (2010: 762), the relation between blogs and marketing are closely related. On the one hand, a blog can be the part of a marketing policy promoted by the company (the blog is seen here as an instrument used to promote the products/services of the company/organization). In this case, the blog helps to present products 
and services promoted by the company or the ideas and economics but also the common goals of the company. At the same time, this type of blogging will allow the company to monitor clients' reactions to launched products or the company's performance. The advantage of these blogs is that it provides a platform to elucidate the misunderstandings that can appear about the promoted products and services. On the other hand, a blog can also act as a final product of a marketing company (Filimon et al. 2010). Some businesses specialize in creating business blogs to reach more potential customers. The success of corporate blogs depends on the attitude of the company's departments. Of course, successful corporate blogs work much better and address customers if the marketing department is not the only one involved in creating the image of the company but also employees become part of the company's blog. In this case, corporate blogs can appeal not only to consumers and potential customers but also to a professional audience, including students in economics.

Both types of blogs are suitable didactic material in teaching business English. These blogs provide a sufficient platform for the presentation of terms related to economics and management and at the same time convey knowledge about modern economic trends, marketing, or business management. Through these blogs, we can learn about the social philosophy of the company. Blogs are not exclusively of an economic nature, but can also provide information on topics such as corporate social responsibility, including approaches to environmental protection. Many companies are aware of the importance of social responsibility and blogs can provide them with a sufficient platform to present their social activities. Some corporate blogs are designed to provide customers with additional product information and, where appropriate, a platform for them to suggest improvements. Blogs can be also used to provide user manuals among other information about the products.

\section{Research methods}

In the research, we decided to use quantitative methods that enabled us to find exact results. We used a pre-test to get the information about students' initial level of knowledge of business English prior to the experimental activity and a post-test which was carried out after completion of an experiment to measure students' achievement and the effectiveness of the experiment. We conducted the experiment for the verification of hypotheses. The last method we used was a questionnaire to get information about the knowledge, opinions, and attitudes of respondents about using weblogs in the 
educational process. The questionnaires designed by researchers were anonymous. They prepared two questionnaires. The first one, which was used before the experiment, consisted of 5 and the second one, which was filled in by respondents after the experiment, consisted of 6 questions. The total number of questions was 11: Do you think that the Internet should be used more in the teaching process? Do you know what a weblog is? Do you think the weblog can be used in the teaching process? Which of the four skills do you think you need to improve? Which of the four skills do you think is most neglected in teaching? What are the benefits of using a blog to study business English? What are the disadvantages of using a blog to study business English? What problems have you encountered during blogging? Did writing blog posts help you to improve your writing skills in business English? Did you enjoy writing and publishing posts? Do you find using a blog motivating for you to study the business English language harder?

The experiment was carried out with two groups of respondents the control and experimental group. The respondents, 60 students who participated in the experiment, were first-year students at the University of Economics. We chose a lower number of respondents because of the specificity of the experiment, which is very timeconsuming, given that it was necessary to provide students with the necessary help in case of publishing problems, as well as to continually check respondents blogging and inform them of their contributions. In this way, respondents were further motivated to publish.

The experiment was conducted in the academic year 2018/2019. In the control group, the teaching of business English proceeded traditionally, i.e. using traditional media (textbook, compact disc player). The experimental group was taught unconventionally, using a weblog as a support of the traditional language teaching in the classroom.

Experimental research consisted of two parts. In the first part of the research, we focused on the determination of the starting state of writing skill and therefore we decided to use the questionnaire and pretest as the research methods, which allowed us to capture and statistically evaluate the factors that affect writing. We tried to characterize the problems associated with business writing skills. The second part was the experiment itself, in which both groups of respondents, the experimental and control group, participated. At the end of the experiment, respondents took the post-test and completed the second questionnaire.

The research focused on finding answers to the following questions: Is the weblog a web tool that can be used as a complement 
to the English language teaching? How does the use of weblog affect the motivation of respondents in studying business English in comparison to the respondents who do not use a weblog as a complement in studying the business English language? Does the use of weblog in learning languages improve the business writing skills of respondents?

\section{Results}

At the very beginning of the experiment, we determined hypotheses: $\mathrm{HO}$ (null hypothesis): Weblog-supported teaching does not affect the business writing skills of respondents; $\mathrm{H} 1$ (alternative hypothesis): Weblog supported teaching improves business writing skills; H2 The use of weblog in teaching business English has a positive effect on the motivation of respondents to study the English language.

The next step in our two-group experiment was to establish the level of writing through diagnostic testing writing skills in the experimental and control groups. In the evaluation of business writings, we used correction symbols (SS (spelling error), WO (mistake in word order), G (grammar), T (wrong verb tense), C (concord mistake), WW (wrong word), ?M (the meaning is unclear), $\Lambda$ (something has been left out), $\mathrm{P}$ (punctuation mistake), (something is not necessary), $\mathrm{F} / \mathrm{I}, .$. ) used by J. Harmer (2007: 111). The analysis of data showed that the writing skills were in both groups, experimental and control, almost at the same level. Students in the experimental group had made 362 mistakes in their papers. The average number of mistakes made by a student was 12,06 . Students in the control group had made 342 mistakes and the average number of mistakes made by a student was 11,4. Areas in which respondents had made most mistakes were: wrong word order, using wrong words (eg. Greece kitchen instead of Greek kitchen), omitting articles, prepositions, etc.

The students of the experimental and control group were trained during the experiment to such an extent that was required by the university curriculum. Students in the experimental group took not only training in writing in the language classroom, but they also published their entries on the weblogs.

Every member of the experimental group was supposed to publish at least two posts a week during 3 months period. The choice of the materials they used as a basis for preparing their posts was up to the students themselves, i.e. they should use mainly economics blogs, but also economics English newspapers, English magazines, Slovak newspapers, Slovak magazines, etc. Each student had created a portfolio of their work. The total number of posts in the experimental group was 518 , i.e. the average number of student contributions was 17.2 , i.e. not 
all students completed the task to publish at least 2 posts a week. The time when they wrote their posts was up to them, i.e. they chose the time and place which were the most convenient for them. The goal was to write the posts that were authentic, and interesting. The length of the post was set to 120 words.

At the end of the experiment respondents filled in the questionnaire. The outcome of this survey revealed that most of the students had found weblog as a tool that helped them to improve their business writing skills, enabled them self-expression, and motivated them to write.

The experiment was concluded with the post-test which was used to verify the level of business writing skills in the experimental and control group. The experimental group made 189 mistakes in their papers. The average number of mistakes made by a student was 6.3 . The control group made 385 mistakes and the average number of mistakes made by a student was 12.83 . Areas in which respondents made most mistakes were: using wrong tenses, wrong word order, using wrong words, omitting articles, prepositions, etc.

Final testing in both experimental and control groups proved that our assumption was correct and the results of the experimental group were better than those of the control group. We used Student's t-test to evaluate whether the differences between the pre-test and post-test are statistically significant or random. After analysis of collected data related to the experimental group, we had to reject $\mathrm{HO}$ (null hypothesis) because the outcome of the $t$-test $(t=6.6967)$ is much greater than the critical value $(\alpha=0.01)$. We had to, therefore, reject the null hypothesis and accept the alternative hypothesis ( $\mathrm{H} 1)$ that Weblog supported teaching improves the business writing skills. Thus, the differences between the number of errors in the pre-test and the post-test were not accidental and writing and publishing posts had led to a significant improvement in student business writing skills.

The analysis of the results achieved by the control group in the pretest and the post-test did not differ significantly. On average, the number of errors even increased slightly. Thus, we can see that respondents who took part in the traditional teaching process in the classroom had not achieved improvement in writing abilities during the three-month experiment period.

For proving or disproving hypothesis $\mathrm{H} 2$ (The use of weblog in teaching has a positive effect on the motivation of respondents to study business English language) we used the questionnaire which consisted of 6 questions. Two questions were closed-ended and respondents could answer them by a simple one-word answer "yes" or „no". Four 
questions were open-ended and the respondents were asked to provide feedback in their own words.

The respondents thought after three months of blogging that writing and publishing posts helped them to improve not only the business writing skills, but they also improved and enriched business vocabulary. Surprisingly, only nine students were motivated to study the business English language harder and devote more time to writing posts. We see the reasons for this outcome in fact that writing and publishing posts on the weblog are time-consuming and it had an impact on the respondents' attitude to the weblog. The responses confirmed the hypothesis that Weblog supported teaching improves the business writing skills of respondents.

\section{Discussion}

The results of the experiment and analysis of the data obtained from the questionnaire showed that using weblogs as support of traditional educational process had not only advantages but also disadvantages such as a problem with feedback, time-consuming, problem to find a topic for writing, necessity of the Internet access, possibility of copying (plagiarism), only written form, stereotyped. The respondents saw "feedback" as one of the biggest problems. For demonstrating we give some examples the respondents ran into during the experiment: because I could not learn from the mistakes; because I did not see them; since no one commented on the blogs; I did not know if the grammar and content of the text were correct; low control.

We were aware of these problems throughout the experiment. With such a large number of students and a high number of lessons, it was very difficult to correct every post and write a comment on it. To solve this problem, the teacher wrote out the most common mistakes students had made in the posts on the whiteboard and explained them. The teacher carried out this explanation process at the beginning of each lesson.

The respondents saw preparing and studying materials, writing, and publishing posts as the second biggest problem because these processes were time-consuming. This fact had an impact on their motivation. The respondents were motivated to publish the posts at the beginning of the experiment. It was because of the novelty of using blogs as support of teaching language but as the experiment proceeded, they were losing motivation and some of them were demotivated. The reason for this lay in the fact that writing and publishing posts were, as we mentioned, time-consuming. 
In the questionnaire, we asked the respondents "What problems did you encounter in blogging?" It was an open question and we divided the responses into 4 categories: 1 . problem to publish a post ( could not publish it; lengthy editing of the final text; I did not find interesting news on the topic; multiple attempts to publish the same post;) 2. technical problems (it did not work; it didn't want to follow my commands; login issues), 3. problem to publish a video (my attempts to post a video to the weblog were in vain; a problem with video), 4. problem to publish picture (bad image size). Respondents were informed that problems with publishing posts could be reported at the beginning of the experiment when they were also informed that posts had to be in the form of Html. However, we realized that according to the respondents' answers there could also be other problems such as the poor Internet connection.

\section{Conclusions}

The outcomes of the experiment showed that students from the experimental group had made a significant improvement in business writing skills through publishing posts on the weblog. The weblog also had an impact on student's motivation to write and study business English harder but not as high as we expected. The respondents appreciated the novelty of the weblog and its possibilities that enabled them to present themselves on the Internet. The students themselves said that the weblog had an impact on improving business-writing skills; broaden their vocabulary, allowing them to express themselves publicly.

The weblog is suitable for all ages, language levels, and subjects. Its biggest disadvantage is the time required not only for students writing papers but especially for the teacher who has to check and writes the comments on all papers. One solution for providing feedback to students is to make them aware of the mistakes they made, not individually, but as a group at the beginning of the lesson where the teacher explains the mistakes that occurred in blogs.

The results of the research demonstrated the potential of using blogs as a complement to language teaching. The advantages of using weblogs are improving business writing skills and their influence on students' motivation to write and study business English harder. The weblog is just one of the many current Web 2.0 applications. It can be a very effective and motivating tool to improve business writing and reading skills, provided that students regularly perform the task assigned to them on the weblog. 


\section{Acknowledgments}

This research was carried out within the project KEGA 005EU$4 / 2018$ aimed at the research of using weblogs as a support of a traditional educational process.

\section{Works Cited:}

Agerdal-Hjermind, Anette. "Organizational blogging: a case study of a corporate weblog from an employee perspective." Corporate Communications: An International Journal 19.1 (2014): 34-51.

Anglemark, Linnéa, and John, Anglemark. "The Use of English-Language Business and Finance Terms in European Languages." International Journal of Business Communication 55.3 (2018): 406-440.

Arquero, José L., and Romero-Frías, Esteban. "Using social network sites in higher education: An experience in business studies." Innovations in Education and Teaching International 50 (2013): 238-249.

Bener, Esra, and Yildiz, Senem. "The Use of Blog Activities to Promote Reflection in an ELT Practicum." Australian Journal of Teacher Education 44.8 (2019). Web. 19 Februar 2020 <https://ro.ecu.edu.au/ajte/vol44/iss8/3>.

Berners-Lee, Tim. Weaving the World Wide Web. London: Orion Business Books, 1999.

Brake, David R. "Are We All Online Content Creators Now? Web 2.0 and Digital Divides." Journal of Computer-Mediated Communication 19 (2014): 591609.

Cramer, Michelle L. (2013): "Content Marketing as a Core Business Strategy." EContent 36.8 (2013): 10-15.

Crystal, David. Language and the Internet. Cambridge: University Press, 2006.

du Preez, Madely. "Blogging for Creatives: How Designers, Artists, Crafters and Writers Can Blog to Make Contacts, Win Business and Build Success." Online Information Review 36.6 (2012): 931-932.

Dudley-Evans, Tony, and St John, Jo. Developments in English for Specific Purposes. Cambridge: Cambridge University Press, 1998.

Elega, Adeola Abdulateef. "Digital Conversations on the Blogosphere." Online Journal of Communication and Media Technologies 8.2 (2018): 39-54. Web. 19 Februar 2020 <https://www.ojcmt.net/download/digitalconversations-on-the-blogosphere.pdf $>$.

Farmer, Brett, Yue, Audrey, and Brooks, Claire. "Using blogging for higher order learning in large cohort university teaching: A case study." Australasian Journal of Educational Technology 24.2 (2008): 123-136.

Filimon, Stremtan, Ioan, Achim Moise, Alexandru, Radu Lucian and Ruxandra, Radoviciu. "Blog marketing - a relevent instrument of the marketing policy." Annales Universitatis Apulensis Series Oeconomica 12.2 (2010): 760-765.

Habermann, Julia. "Weblogs as a source of business news and information." Online 29.5 (2005): 35-37. 
Harmer, Jeremy. How to teach writing. Harlow: Pearson Education Limited, 2007.

Hartman, Tilo von. "Blogs im Wahlkampf - Möglichkeiten und Perspektiven." Wahlkämpfe in Deutschland. Fallstudien zur Wahlkampfkommunikation 1912 - 2005. Ed. Nicolaus Jackob. Wiesbaden: VS Verlag, 2007. 332-344.

Hockly, Nickly, and Dudeney, Gavin. How to teach English with technology. Harlow: Pearson Education Limited, 2007.

House, Juliane. "English as a lingua franca: A threat to multilingualism?" Journal of Sociolinguistics 7.4 (2003): 556-578.

Hrdličková, Zuzana. "Business English Idioms vs. Business Terms." Lingua et Vita 6.2 (2017): 22-29.

Ifinedo, Princely. "Roles of perceived fit and perceived individual learning support in students' weblogs continuance usage intention." International Journal of Educational Technology in Higher Education 15.7 (2018). Web. 19 April 2020 $<$ https://educationaltechnologyjournal.springeropen.com/articles/10.11 86/s41239-018-0092-3>.

Išoraité, Margarita. "Entrepreneurship and Blog Marketing." Entrepreneurship and Sustainability Issues 2.3 (2015): 171-178.

Jones, Briab, and Iredale, Norma. (2009): "Entrepreneurship education and Web 2.0." Journal of Research in Marketing and Entrepreneurship 11.1 (2009): 66-77.

Kankaanranta, Anne, Louhiala-Salminen, Leena, and Karhunen, Paivi. “English in multinational companies: implications for teaching "English" at an international business school." Journal of English as a Lingua Franca 4.1 (2015): 125-148.

Karabacak, Gozde, and Genç, Merve. "The Use of Blogs as an Example of Internet Entrepreneurship: Turkish Travel Blogs." Procedia Computer Science 158 (2019): 869-876.

Karpova, Olena (2017): "The Implementation of the Multimedia Approach to Teaching Business English." Advanced Education 8 (2017): 10-15.

Kitchakarn, Orachorn. "Developing Writing Abilities of Efl Students Through Blogging." Turkish Online Journal of Distance Education 15.4 (2014): 3447.

Kluknavská, Alena, and Hruška, Matej. "We Talk about the "Others" and You Listen Closely the Extreme Right Communication on Social Media." Problems of Post-Communism 66.1 (2019): 59-70.

Kovalchuk, Olena, and Krasnokutska, Inessa. "Using Blogs in Teaching English to Philology Students." Advanced Education 7 (2017): 146-153.

Laborda, Jesus Garcia, and Litzler, Mary Frances. "English for Business: Student Responses to Language Learning Through Social Networking Tools." ESP Today-Journal of English for Specific Purposes at Tertiary Level 5.1 (2017): 91-107.

Lacina, Jan, and Griffith, Robin. "Blogging as a Means of Crafting Writing." The Reading Teacher 66.4 (2012): 316-320. 
Lee, Jieun, and Bonk, Curtis J. "Social network analysis of peer relationships and online interactions in a blended class using blogs." The Internet and Higher Education 28 (2015): 35-44.

Lennon, Sherilyn, and Barnes, Naomi. "A New Materialist take on the possibilities and impossibilities of becoming a scholarly blogger." International Journal for Academic Development (2020): 1-20.

Li, Dan, and Chen, Binrong. "Technology-Enhanced Business English Writing Teaching." International Journal of Information and Education Technology 7.9 (2017): 700-706.

Lin, Ming Huei (2013): "Effects of Classroom Blogging on ESL Student Writers: An Empirical Reassessment." Asia-Pacific Education Researcher 23.3 (2013): 577-590.

Ma, Yanjing. "Studying the present situation of web-based English learning in business English schools." International Journal of Continuing Engineering Education and Life-Long Learning 22.1-2 (2012): 24-35.

Murray, Liam, and Hourigan, Triona. "Blogs for Specific Purposes: Expressivist or Socio-cognitivist Approach?" ReCall 20.1 (2008): 82-97.

Murugesan, San “Understanding Web 2.0." IT Professional 9.4 (2007): 34-41.

Oravec, Jo Ann. "Bookmarking the World: Weblog Applications in Education." Journal of Adolescent \& Adult Literacy 45.7 (2002): 616-621.

Pereira, Cledir Rocha et al. "Using the Blog's Space in the School's Routine." Revista Inclusiones 6.4 (2019): 207-219.

Quible, Zane K. "Blogs and Written Business Communication Courses: A Perfect Union." Journal of Education for Business 80.6 (2005): 327-332.

Ráthonyi Gergely, and Várallyai László. "Web 2.0 and tourism". Proceedings of the International Conference on Information and Communication Technologies for Sustainable Agri-production and Environment (HAICTA 2011). Ed. Michail Salampasis and Aris Matopoulus. Skiathos, 8-11 September, 2011, 27-39.

Sing, Robert P., and Singh, Lisa O. "Blogs: Emerging Knowledge Management Tools for Entrepreneurs to Enhance Marketing Efforts." Journal of Internet Commerce 7.4 (2008): 470-484.

Solomon, Gwen, and Schrum, Lynne. Web 2.0 how-to for educators. Washington: International Society for Technology in Education, 2010.

Šipragić-Đokić, Sanela. "Teaching Business English - From Foreign Language to Basic Skill Required by the Global Market." Časopis za ekonomiju i tržišne komunikacije 1.1 (2011): 153-159.

Zoranić, Amela Lukač. "Business English as a Part of English Language for Specific Purposes." Folia Linguistica et Litteraria 1.1-2 (2010): 359-364.

\section{VYUČOVANIE OBCHODNEJ ANGLIČTINY S PODPOROU WEBLOGOV}

V príspevku sme sa zamerali na sprostredkovanie výsledkov výskumu zameraného na používanie weblogov ako formy doplnku $k$ tradičnému 
prezenčnému vyučovaniu a ich vplyvu na rozvoj zručností písania v obchodnej angličtine. Ciel'om výskumu bolo dokázat', že weblog mal pozitívny vplyv na zlepšenie zručností $v$ písaní a na motiváciu študentov venovat' sa písaniu príspevkov v cudzom jazyku. Pri výskume sme použili experiment kombinovaný o kvantitatívne výskumné metódy. Výskum sa uskutočnil na Ekonomickej univerzite $v$ Bratislave a zúčastnilo sa na ňom 60 respondentov. Pre-testom a post-testom sme zistili, do akej miery boli ovplyvnené schopnosti písania v obchodnom styku respondentov experimentálnej skupiny využitím weblogov pri výučbe obchodnej angličtiny. Na analýzu získaných údajov sme použili študentský test. Výsledky potvrdili, že použitie weblogu pri výučbe obchodnej angličtiny malo vplyv na rozvoj zručností v písaní. Dotazník sme použili na zber údajov z prieskumov zameraných na zistenie, do akej miery použitie weblogu ovplyvnilo motiváciu respondentov písat vo väčšej miere v cudzom jazyku. Analýza odpovedí potvrdila, že respondenti vnímali weblog ako novú netradičnú formu doplnku tradičného vyučovania, čo malo vplyv na ich motiváciu venovat' sa viac písaniu v cudzom jazyku. Výskum potvrdil, že weblog ako jeden z nástrojov Web 2.0 má pozitívny vplyv na rozvoj zručností v písaní pri vyučovaní obchodnej angličtiny.

Kl'účové slová: obchodná angličtina, marketingové nástroje, informačné a komunikačné technológie, ekonomický blog, Web 2.0. 